\title{
Osmar Alves Carrijo: parte um grande nome do mundo das hortaliças
}

Paulo Eduardo de Melo ${ }^{1}$; Geni Litvin Villas Boas ${ }^{2 *}$; Ronessa B de Souza ${ }^{2}$

${ }^{1}$ Embrapa Estudos e Capacitação, Av. W3 Norte, Final (s/n), Edifício Embrapa Sede, Bloco D, 70770-901 Brasília-DF; ${ }^{2}$ Embrapa Hortaliças, C. Postal 218, 70351-970 Brasília-DF; *Pesquisadora aposentada; paulo.melo@embrapa.br

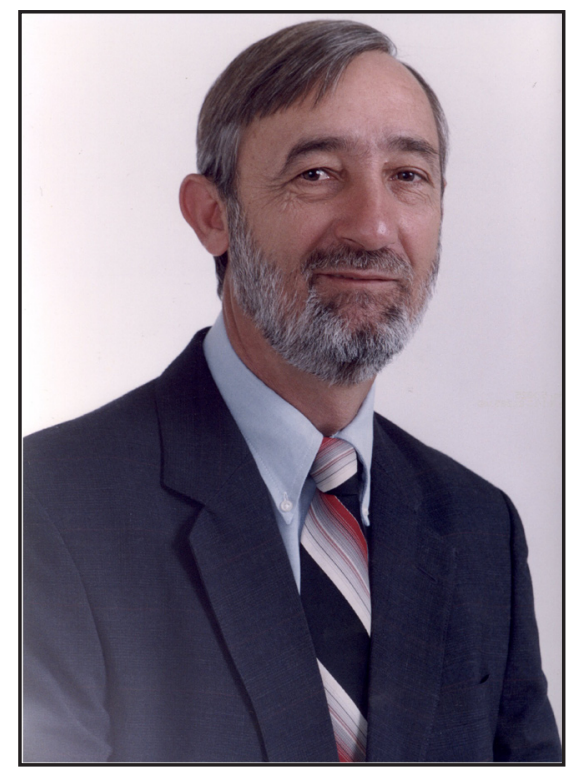

No último domingo, 12 de dezembro, nosso grande amigo, Osmar Alves Carrijo, aos 61 anos, sofreu um infarto fulminante, do qual não conseguiu se recuperar. Osmar era agrônomo, formado pela Universidade de Brasília (1976), com mestrado em Irrigação e Drenagem (ESALQ, 1980), doutorado em Solos e Irrigação, (Oregon State University, 1988) e pos-doc em Manejo e Tratos Culturais (Florida State University, 1998). Pesquisador da Embrapa Hortaliças desde 1976 até 2007, quando se aposentou; Osmar era ainda professor associado na Universidade de Brasília, onde atuava junto à pós-graduação.

Como pesquisador, até mesmo pela sua origem e vínculos com o setor rural, que não só fez questão de manter, mas pelos quais sempre nutriu profundo orgulho, Osmar sempre optou pelas linhas de pesquisa e formas de atuação mais aplicadas, mais próximas aos agricultores e à transferência de tecnologia. Ainda assim, participou ativamente da vida científica da olericultura, tomando parte em congressos, reuniões e eventos e publicando livros e trabalhos. Cabe muito justamente ressaltar que seus trabalhos "Fibra da casca do coco verde como substrato agrícola" (Horticultura Brasileira 20: 533-535, 2002) e "Produtividade do tomateiro em diferentes substratos e modelos de casas de vegetação (Horticultura Brasileira 22: 5-9, 2004) são, entre os artigos publicados em Horticultura Brasileira, respectivamente o segundo e nono mais requisitados na base SciELO (www.scielo.br/hb, visitado em 14 de dezembro de 2010).

Além da competência científica, Osmar sempre demonstrou habilidade no trato com as pessoas, fruto da sua conduta ética e franca, que sempre inspirou confiança, mas também conciliadora e avessa ao confronto. Assim, com grande habilidade e livre trânsito entre os colegas, Osmar exerceu, por diversas vezes, funções de gestão na Embrapa Hortaliças, tanto como Chefe Administrativo (de 1989 a 1990 e de 2003 a 2007), quanto como Chefe de Pesquisa e Desenvolvimento (de 1990 a 1991) e, também, Chefe Geral (1991-1993). Na ABH, além de associado com ativa participação, Osmar pertenceu à diretoria nas duas gestões da Prof ${ }^{a}$ Rumy Goto.

Osmar deixa a esposa, Dinália, três filhos e dois netos. Ao nosso amigo, dedicamos nosso respeito, nossa saudade e nosso profundo agradecimento por tudo, e não foi pouco, que com ele e dele pudemos aprender. 